\title{
Traffic accident-related injuries in horses
}

\author{
Barbara K. Schwenk, Anton E. Fürst and Andrea S. Bischofberger \\ Equine Hospital, Vetsuisse-Faculty, University of Zürich, Switzerland
}

\begin{abstract}
Summary: Horses involved in road traffic accidents (RTAs) are commonly presented to veterinarians with varying types of injuries. The aim of this study was describe the pattern and severity of traffic accident-related injuries in horses in a single hospital population. Medical records of horses either hit by a motorized vehicle or involved in RTAs whilst being transported from 1993 to 2015 were retrospectively reviewed and the following data was extracted: Signalement, hospitalisation time, month in which the accident happened, cause of the accident, place of the accident and type of vehicle hitting the horse. Further the different body sites injured (head, neck, breast, fore limb, abdomen, back and spine, pelvis and ileosacral region, hind limb, tail and genital region), the type of injury (wounds, musculoskeletal lesions and internal lesions) and the presence of neurological signs were retrieved from the medical records. 34 horses hit by motorized vehicles and 13 horses involved in RTAs whilst being transported were included in the study. Most of the accidents where horses were hit by motorized vehicles occurred during December (14.7\%) and October (14.7\%), horses were most commonly hit by cars (85.3\%) and the majority of accidents occurred on main roads (26.5\%). In $29.4 \%$ of the cases, horses had escaped from their paddock and then collided with a motorized vehicle. Most of the accidents with horses involved in RTAs whilst being transported occurred during April (30.8\%) and June (23.1\%). In $76.9 \%$ of the cases the accident happened on a freeway. In the horses hit by motorized vehicles the proximal hind limbs were the body site most commonly affected (44.1\%), followed by the proximal front limbs (38.2\%) and the head (32.4\%). When horses were involved in RTAs whilst being transported the proximal fore limbs (61.5\%), the proximal hind limbs (53.8\%) and the distal hind limbs, back and head (38.5\% each) were the most common injured body sites. Wounds were the most common type of injury in both groups (85.3\% hit by motorized vehicle, $76.9 \%$ transported ones). In horses hit by a motorized vehicle $35.3 \%$ suffered from fractures, in $20.6 \%$ a synovial structure was involved and in $5.9 \%$ a tendon lesion was present. $14.7 \%$ suffered from internal lesions and $14.7 \%$ showed neurologic symptoms (40\% peripheral, $60 \%$ central neurologic deficits). On the other hand, in horses involved in a RTA whilst being transported $30.8 \%$ suffered from fractures. There were no synovial structures injured and no tendon injuries were present. Furthermore there were no internal lesions present and only one horse involved in a RTA showed central neurologic symptoms. Injuries of horses being hit by a motorized vehicle were more severe than when horses were protected by a trailer and involved in a RTA whilst being transported. The study has been able to identify the different injury types of traffic accident-related injuries in horses. Awareness of the nature of these injuries is important, to avoid underestimation of their severity.
\end{abstract}

Keywords: traffic / horse / injury / body site / accident / trauma

Citation: Schwenk B. K., Fürst A. E., Bischofberger A. S. (2016) Traffic accident-related injuries in horses. Pferdeheilkunde $32,192-199$

Correspondence: Dr. Barbara K. Schwenk, Equine Hospital, Vetsuisse Faculty, University of Zürich. Winterthurerstrasse 260, 8057 Zürich, Switzerland; E-mail: bschwenk@vetclinics.uzh.ch

\section{Introduction}

Road traffic accidents (RTAs) are a major cause of deaths in humans, leading to 25'900 deaths in Europe in 2013. Luckily, numbers are decreasing constantly since 2003, where 50 '400 victims were counted, but nevertheless the mortality rate remains high (European Commission - Directorate General for Mobility and Transport, 2015). In Switzerland, approximately every 36 hours a human being involved in a RTA dies, which led to 243 people dying in RTAs in 2014 (Eidgenössisches Departement des Innern EDI 2014, Bundesamt für Strassen ASTRA 2015).

Not only humans but also animals are often victims of RTAs. Wild animals such as deer and foxes are probably the most common animals involved, of which collisions of deer with vehicles occur most frequently. In Europe greater than 0.5 million collisions per year are estimated. In the US the number is three times higher, rising to 1.5 million collisions per year (Langbein et al. 2011 , Hothorn et al. 2015).

Dogs and cats are the most commonly involved pets in RTAs. The number of dogs and cats annually killed by RTAs is not statistically defined. However there are multiple studies reporting the injury types of these animals. Commonly reported injuries were fractures (Corr 2012) and pelvic traumas (Mee- son and Corr 2011). Katic et al. state that, although not frequently seen in dogs and cats, diaphragmatic hernias remain a possible consequence after RTAs (Katic et al. 2007). A study published in the UK in 2011 found that for cats with outdoor access, death due to a RTA was the fourth most common cause (Meeson and Corr 2011).

In Switzerland overall 103'010 horses were counted in 2012 (Eidgenössisches Departement für Wirtschaft, Bildung und Forschung Agroscope 2015 ). The number of horses involved in RTAs in Switzerland is not available. Nevertheless, every year cases of horses involved in RTAs are presented to our clinic, either when standing in a horse trailer that was subject to a RTA or after being directly hit by a motorized vehicle.

Nowadays it is very common to transport horses and as a consequence the risk of horses being involved in RTAs whilst being transported is increasing. Furthermore, in countries such as Switzerland it is nearly impossible to trail ride without having to cross roads with heavy traffic or even having to ride in traffic. Additionally, horse paddocks and stables are often close to roads with a high traffic volume. Horses respond to danger with a fight-or-flight instinct reaching high levels of speed within a few seconds. Thus, in case of a horse breaking out whilst stabled or whilst paddocked or when incidences 
happen during riding the risk of horses being involved in RTAs is omnipresent.

The aim of this study was to retrospectively describe the pattern and severity of traffic accident-related injuries in horses in a single hospital population. The cases were divided into horses hit by a motorized vehicle and horses involved in RTAs whilst being transported.

\section{Material and methods}

Medical records of horses admitted to the Equine Hospital, Vetsuisse-Faculty, University of Zürich, Switzerland between 1993 and 2015 with injuries following RTAs were retrospectively reviewed. Seven horses, euthanized at the scene of the accident and twelve horses with incomplete medical records on clinical examination findings were excluded from the study. Horses were divided into 2 groups: I - Horses hit by a motorized vehicle; II - Horses involved in RTAs whilst being transported.

Factors retrieved from the medical records and compiled in an excel data sheet included: Signalement, hospitalisation time, month in which the accident happened, cause of the accident, place of the accident, type of vehicle hitting the horse. Further the different body sites injured were retrieved from the medical records (head, neck, breast, fore limb, abdomen, back and spine, pelvis and ileosacral region, hind limb, tail and genital region). The type of injury was recorded and divided into wounds, musculoskeletal lesions and internal lesions. Wounds were subdivided into superficial (only skin affected) and deep (skin perforation) (figure 1). If a horse had both superficial and deep wounds, the horse was classified according to the worse wound type (deep). Musculoskeletal lesions were subdivided into fractures, lesions involving synovial structures and tendon lesions. The involved fractures and synovial structures were described in detail and categorized.

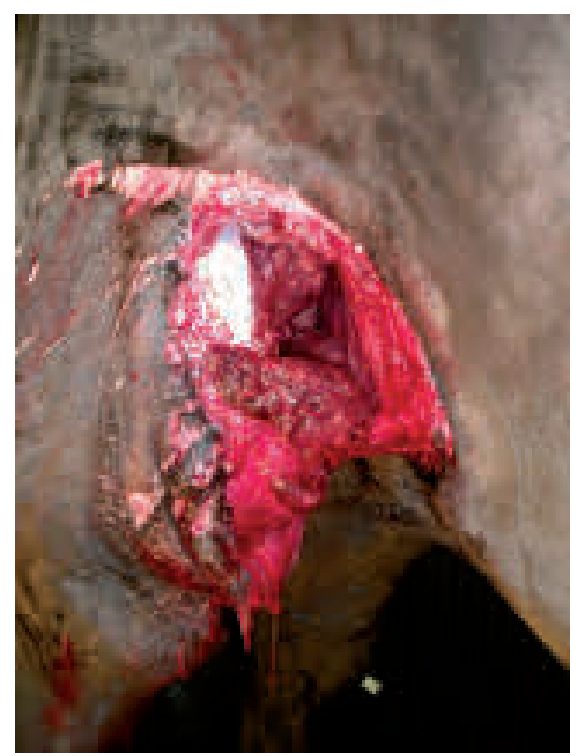

Fig. 1 Image showing a deep perforating wound with a complete tear of the musculus rectus femoris in a horse, which was hit by a car.

| Die Aufnahme zeigt eine tiefe, perforierende Wunde mit einer kompletten Ruptur des M. rectus femoris. Das Pferd war von einem Auto angefahren worden.
Internal lesions were not subdivided due to the low number in this group and were described separately. Furthermore the number of affected body sites and the number of lesions per body site was assessed in each group. The presence of neurological signs was also retrieved from the medical records.

\section{Data analysis}

The group I - horses hit by a motorized vehicle and the group III - horses involved in RTAs whilst being transported were analysed separately. Mean, standard deviation and range were used to describe continuous variables and frequencies in percentages were used to describe categorical variables. The descriptive statistical analysis was performed using SPSS (SPSS, Chicago INC).

\section{Results}

Group I - Horses hit by a motorized vehicle

Five horses, euthanized at the scene of the accident and eight horses with missing information in their medical records were excluded from the study (figure 2). Thirty-four horses with a mean age of $9.1 \pm 4.8$ years (range: $1-21$ years) were included in this group. Of these $41.2 \%$ were geldings, $44.1 \%$ were females and $14.7 \%$ stallions. Breeds were distributed as follows: $50 \%$ Warmbloods, $14.7 \%$ donkeys, $11.8 \%$ ponies, $8.8 \%$ Arabian horses, $8.8 \%$ Islandic horses and $5.9 \%$ others. Most of the accidents occurred during the months: December $(14.7 \%)$ and October (14.7\%), February (11.8\%), May $(11.8 \%)$ and November (8.8\%) and June (8.8\%). In the months January, March, April and July two accidents occurred in each month (each 5.9\%). In August and September one accident occurred in each month (each $2.9 \%$ ).

Horses were most commonly hit by cars (85.3\%, $\mathrm{n}=29)$ and less often by tractor-trailers, tractors or motorcycles $(2.9 \%$, $\mathrm{n}=1$ each). In $6 \%$ of the horses information on the vehicle type was missing in the medical record $(n=2)$. The majority of the accidents occurred on main roads (26.5\%). Less commonly horses were hit on trails $(5.9 \%)$ or on freeways $(2.9 \%)$. In

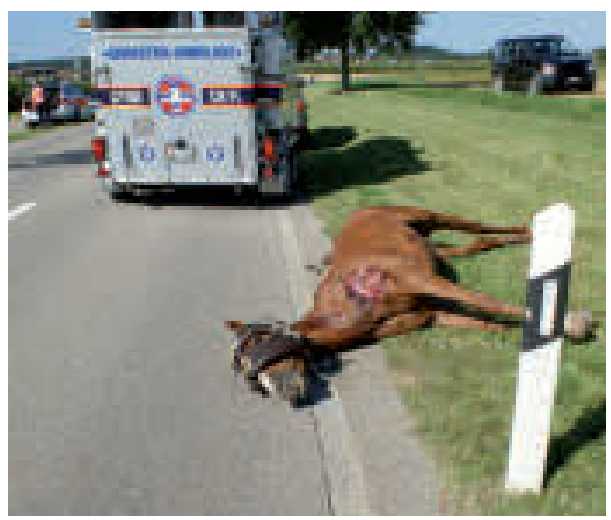

Fig. 2 Image showing a dead polo pony following a frontal collision with a car. The pony died on the scene of the accident. The pony had a tear in its pleura pulmonalis and in his lung parenchyma accompanied by a massive hemothorax. | Die Aufnahme zeigt ein totes Polopony nach einer Frontalkollision mit einem Auto. Das Pony verstarb noch auf der Unfallstelle. Ein Riss in der Pleura pulmonalis, sowie im Lungenparenchym waren begleitet von einem hochgradigen Hämothorax. 
Fig. 3 Bar chart showing the percentages of the different body sites injured of horses ( $(n=47)$ presented to the Equine-Hospital, Vetsuisse-Faculty University of Zürich, Switzerland between 1993 - 2015 either having been hit by a motorized vehicle $(n=34)$ or having been involved in a road traffic accident whilst being transported $(n=13)$. Percentages exceed a hundred percent due to multiple body sites injured per horse. | Pferde ( $n=47)$ welche zwischen 1993 2015 im Rahmen eines Verkehrsunfalles vorgestellt worden sind wurden in zwei Gruppen aufgeteilt. In jene, welche von einem motorisierten Fahrzeug angefahren worden sind $(n=34)$ und in jene, welche in einem Anhänger stehend verletzt worden sind ( $n=13)$. Der Graph zeigt die Prozentangaben der verschiedenen, verletzten Körperstellen der Pferde der einzelnen Gruppen auf. Prozentzahlen übersteigen 100\% aufgrund Beteiligung multipler Körperstellen pro Pferd.

Fig. 4 Graph showing the percentages of the different single injury types of horses ( $n$ $=47$ ) presented to the Equine-Hospital, Vetsuisse-Faculty University of Zürich, Switzerland between 1993 - 2015 either having been hit by a motorized vehicle $(n=34)$ or having been involved in a road traffic accident whilst being transported $(n=13)$.

Das Diagramm zeigt die Prozentangaben der verschiedenen, einzelnen Verletzungskategorien auf. Sämtliche Pferde, welche zwischen 1993 - 2015 im Rahmen eines Verkehrsunfalles vorgestellt worden sind $(n=47)$, wurden in zwei Gruppen aufgeteilt In jene, welche von einem motorisierten Fahrzeug angefahren worden sind $(n=34)$ und in jene, welche in einem Anhänger stehend verletzt worden sind $(n=13)$.

$64.7 \%$ of the horses information on the place of the accident was missing in the medical record. One third of the horses had escaped from their paddock and then collided with a motorized vehicle (29.4\%). In $5.9 \%$ of cases the rider fell off the horse whilst trail riding and the horse subsequently collided with a motorized vehicle. Very few horses collided with a motorized vehicle whilst being ridden with the rider on top (2.9\%). In the remaining $61.8 \%$ of the horses information of the circumstances of the accident was missing in the medical record.

The 3 main body sites injured when horses were hit by a motorized vehicle were the proximal hind limbs (44.1\%), the proximal fore limbs (38.2\%) and head (32.4\%). Percentages relate to the total number of body sites injured. The frequencies (in \%) of injured body sites for horses comparing groups I and II) are shown in figure 3.

The distribution of the injury types (wounds, musculoskeletal and internal lesions) is shown in figure 4 . Most of the horses in this group (I) suffered from a wound (29 out of 34 horses). In $65.5 \%$ of these 29 horses, wounds were classified as superficial and in the remaining $34.5 \%$ wounds were classified as deep.

Approximately a third of the horses suffered from fractures $(n=12,35.3 \%)$. Eleven horses had one fracture and one hor- se had two fractures. The horse with two fractures had a closed fracture of the ileum and a closed fracture of the mandibula. Overall there were two open fractures (diaphyseal metacarpus III fracture with open fetlock joint and comminuted pedal bone fracture with open coffin joint). The remaining nine fractures (20.6\%) were closed \{Pedal bone fracture type III $(n=11)$, ischial tuberosity fracture $(n=2)$, comminuted humerus fracture $(n=1)$, fracture in the stifle resulting in multiple small intra articular bone fragments $(n=1)$, rib fracture $(n=2)$, mandibular fracture $(n=1)$, tooth root and alveolar socket fracture $(n=1)$. A fifth of the horses had synovial structures involved (open stifle joint $(n=2)$, open bicipital bursa $(n=1)$, open fetlock joint $(n=1)$, open coffin joint $(n=2)$ and open radio carpal- and intermediate carpal joints $(n=1)\}$.

Only few horses suffered from tendon lesions (severe septic tendinitis of the biceps tendon $(n=1)$ and severe desmitis of the suspensory ligament $(n=1)(5.9 \%))$. Finally, there were two cases among the musculoskeletal lesions, which did not fit into the categories fractures, joints or tendon lesions. The first one was a horse with a right fore limb lameness localized to the foot with suspicion of a contusion. At a later stage a focal osteitis of the lateral palmar process of the pedal bone was found and treated. The second one was a horse with a contusion of the fetlock area. 14.7\% suffered from internal lesions, such as hemoabdomen $(n=2)$, colon rupture $(n=1)$, 
epistaxis, and central neurologic deficits $(n=1)$, pulmonary hemorrhage $(n=1) .14 .7 \%$ of the horses showed neurologic symptoms of which $40 \%$ showed peripheral nerve deficits and the others $(60 \%)$ showed central nervous deficits (figures 6 and 7).

Thirty-four horses were included in the study, of which $91.2 \%$ were treated at the Equine Hospital. The mean hospitalisation time was $11.2 \pm 12.1$ days (range: $0-54$ days). One horse with superficial wounds was discharged after examination. Two horses were euthanized up on arrival at the Equine Hospital due to the severity of their injuries or due to the owners decision (horse 1: several rib fractures, liver tear, hemoabdomen; horse 2: fracture of the stifle with multiple intraarticular fragments). Therefore, 32 out of 34 horses survived to hospital discharge.

\section{Group II - Horses involved in RTAs whilst being transported}

Two horses, which were euthanized at the scene of the accident, were not included in the study. Four horses with missing information in their medical records were excluded from the study. Thirteen horses with a mean age of $10.1 \pm 4.7$ years (range: 4-18 years, one horse with unknown age) were included in this group. Of these $53.8 \%$ were geldings and $46.2 \%$ were females. Breeds were distributed as follows: $69.2 \%$ Warmbloods, $15.4 \%$ ponies, $7.7 \%$ Arabian horses, $7.7 \%$ cold blooded horses. Most of the accidents occurred during April (30.8\%) and June (23.1\%). The rest of the accidents were equally distributed over the whole year. In two horses the trailer they were transported in, was hit by a car and in four horses the trailer they were transported in was hit by a tractor trailer. In seven horses information on the course of the accident was missing in the medical record. In ten horses the RTA happened on a freeway and in one horse the RTA happened on a main road. In two horses information on the place of the RTA was missing in the medical record.

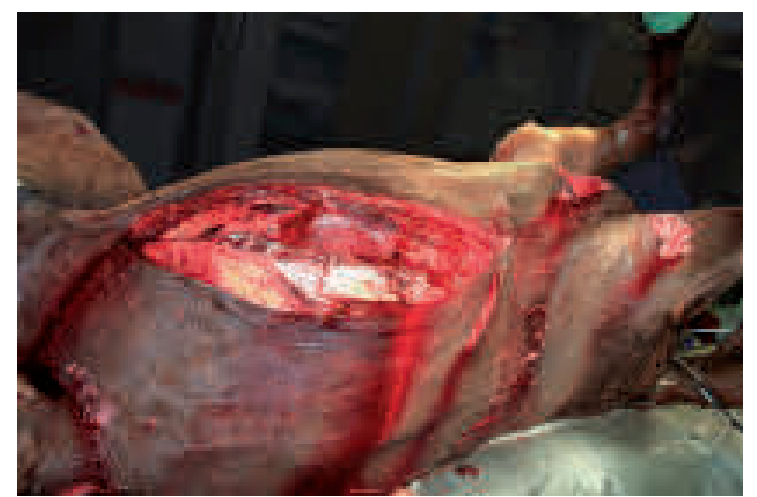

Fig. 5 Image showing a 13 year-old Warmblood gelding under general anesthesia at the Equine Hospital, Vetsuisse-Faculty, University of Zürich, Switzerland. This horse had escaped from a paddock and collided with a car and had sustained a huge abdominal wound. The external and internal oblique abdominal muscle was completely ruptured, the transverse abdominal muscle was partly ruptured but the peritoneum was intact. | 13-jähriger Warmblutwallach in Allgemeinanästhesie. Der Wallach wurde an der Pferdeklinik der Vetsuisse Fakultät der Universität Zürich vorgestellt, nachdem er aus seinem Paddock ausgebrochen und auf ein Auto gesprungen war. Der M. obliquus abdominus internus, als auch der M. abdominus externus waren komplett rupturiert. Der M. abdominus transversus war teilweise rupturiert. Das Peritonaeum war intakt.
The main body sites injured in horses involved in RTAs whilst being transported were proximal fore limbs (61.5\%), proximal hind limbs (53.8\%), and distal hind limbs, back and head (38.5\%). Percentages relate to the total number of body sites injured. The frequencies (in \%) of injured body sites for horses comparing groups I and II) are shown in figure 3. A distribution of the different injury types such as wounds, musculoskeletal and internal lesions are shown in figure 4. Overall, ten horses (76.9\%) suffered from wounds. All these wounds were superficial with the exception of one case, where the horse sustained a deep as well as superficial wound. Approximately a third of the horses suffered from fractures $(30.8 \%, n=4)$. Two horses had one fracture (maxilla $(n=1)$, 1 st and 2 nd coccygeal vertebrae $(n=1)$ ) and two horses had two fractures each (thoracic spinous processes 13-15 and ischial tuberosity; zygomatic arch and orbita). In these cases all the fractures were closed. None of the horses involved in RTAs whilst being

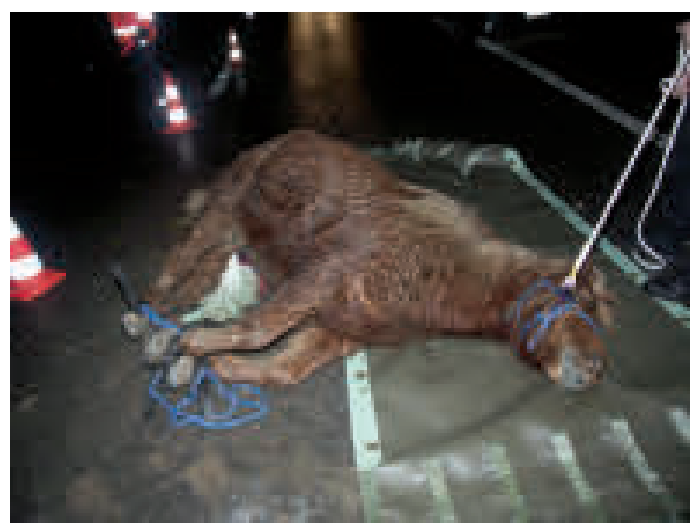

Fig. 6 Image showing an Islandic horse at the scene of the accident after being hit by car. The horse sustained a severe head trauma with multiple cranial nerve deficits. The horse was comatose, showed a general reduction of sensibility in the region of the head and absence of menace reflex of both eyes. I Die Aufnahme zeigt ein Islandpferd nach einer Kollision mit einem Auto. Das Pferd erlitt ein Kopftrauma mit multiplen Hirnnervenausfällen. Das Pferd war komatös, zeigte eine generalisierte Reduktion der Kopfsensibilität und eine beidseitige Abwesenheit des Drohreflexes.

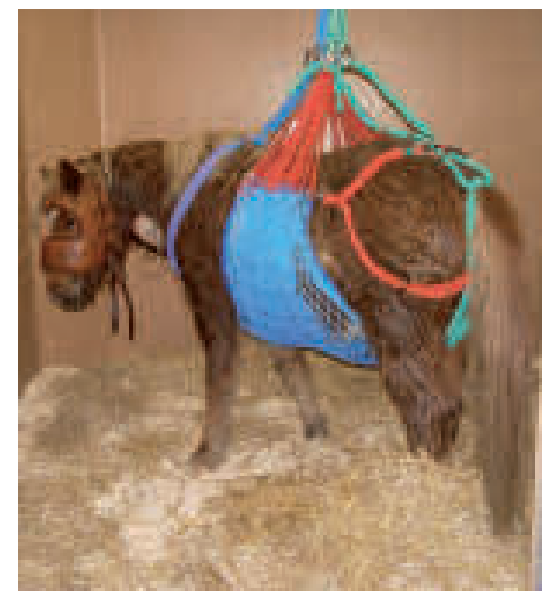

Fig. 7 Image showing the same Islandic horse as shown in figure 6 standing in a large-animal rescue net at the Equine Hospital, Vetsuisse Faculty University of Zürich following treatment. The horse was blind on its left eye after the accident. Besides this, the horse recovered well from the accident. | Die Aufnahme zeigt dasselbe Islandpferd von Abb. 6 stehend im Großtiernetz am Tierspital in Zürich nach der Behandlung. Es erblindete auf dem linken Auge komplett, erholte sich aber ansonsten vom Unfall. 
transported had joint lesions, tendon lesions or internal lesions. Only one horse in this group showed central neurological deficits. Two horses were standing in a trailer, which was overtaken by a tractor trailer. The trailer was streaked and began to totter, but did not turn over. The two horses did not show any lesions, but were stressed and dehydrated. They spent one night on intravenous fluid therapy and under supervision at the Equine Hospital and were then discharged.

Amongst all the presented cases $(n=13)$ the mean hospitalisation time was $6.5 \pm 7.6$ days (range: $1-27$ days). All of the horses survived to hospital discharge.

\section{Discussion}

The aim of this study was to retrospectively describe the pattern and severity of traffic accident-related injuries in horses either hit by a motorized vehicle or injured by an RTA whilst being transported.

Injuries were less severe when horses were confined to a trailer compared to being free. The horse reacts to danger with a fight-or-flight instinct, resulting in large impact forces and predisposing to more severe injuries. It was interesting that when horses were confined in a trailer, lesions were predominantly located on the proximal fore - and hind limbs. Which is in contrast to the horses presented to our hospital sustaining accidental wounds. In these cases trauma to the distal limbs is probably most common. Interestingly in third position we found lesions equally often affecting the distal hind limbs, head and back. This is likely due to the horses hitting their heads, may be also stumbling and falling under the bars of the dividers of the trailers during the RTAs. Horses standing in a trailer must certainly have experienced a certain impact. Nevertheless the trailer seemed to protect them to some degree. None of the horses of this group showed internal lesions, joint lesions or tendon lesions. Approximately three-quarters of the horses of this group suffered from wounds (76.9\%). However only one horse actually sustained a deep wound. In all the other cases the wounds were just superficial.

In horses hit by motorized vehicles fractures were more prevalent than in horses involved in RTAs whilst being transported. There were a multitude of fractures found in the former patients. In horses hit by motorized vehicles fractures of the extremities (hoof, fetlock, stifle), fractures of the head region (mandibula, tooth), fractures of the thoracic region (ribs) and fractures of the pelvis region (tuber ischiadicum and os ileum) occurred. The severity of these lesions should not be underestimated. Interestingly the horses of the RTA group had either fractures in the head region (maxilla, zygomatic arch, orbita), in the back region (spinal processes) or more caudally in the tail or pelvis region (tuber ischiadicum). This type of distribution was similar to the distribution of the injured body sites as discussed above. When horses were involved in RTAs whilst being transported none of the fractures were open, in contrast when horses were hit by a motorized vehicle 2 out of 13 fractures were open. This again may reflect the magnitude of force present when horses are moving freely and can generate speed. Comminuted fractures only happened in freely moving horses hit by a motorized vehicle. Comminuted fractures are caused by high energy impact. The energy is first absorbed by the bone until it fragments and passes over to the surrounding tissue, leading to severe soft tissue damage (Corr 2012). Most likely horses standing in a trailer were protected from these high energy impacts.

According to Ball et al. horse riding is more dangerous than motorcycle riding, skiing, football and rugby (Ball et al. 2007). According to Jagodzinzsky et al. who reviewed horserelated injuries in children, most of the serious injuries in children occur when the rider is thrown from a horse (Ghosh et al.2000, Jagodzinsky et al. 2005). Horses were most frequently hit by a motorized vehicle when breaking out of a paddock not whilst trail riding. This highlights the importance of secure and stable fences of horse paddock especially when horses are kept in near vicinity to busy roads. In $29.4 \%$ of the cases that were hit by a motorized vehicle the accident happened on a road with high volume of traffic (either main roads or free ways). Only $5.9 \%$ of the horses were hit on small trails. Approximately $64 \%$ of the recorded horses in Switzerland are held in the western part of Switzerland and in the German-speaking midland. The traffic in these cantons is high. It is easy to understand that where so many people, horses and traffic come together, the potential of negative interaction and accidents increases. A study of Chapman comes to the conclusion that in comparison to other vulnerable road user groups, horse riders have not received much attention in transport policy and campaigns and training of drivers how to deal with horse riders on public roads is needed (Chapman and Musse/white 2011).

The largest part (29.4\%) of horses hit by a motorized vehicle was a sequelae to horses breaking out of the paddock in the winter months. In the winter months it gets dark earlier. Riders put lucent, shiny protectors on their horses and themselves wear reflective clothing to improve the visibility in the dark when trail riding. Horses out in paddocks rarely wear lucent protectors and when they break out from their paddocks they are especially hard to see for the drivers of motorized vehicles. It is not recommended to let the horses on unsecured paddocks in the dawn or in the night. On the other hand accidents with trailers happened more often in the months April and June. This is likely to be related to the fact that most of sports competitions take place in Spring and Summer and it is possible that there are more trailers on the roads in this period of the year.

A study of Corr (2012) demonstrates that cats less than two years old are more likely to be involved in a RTA (Corr 2012). It may be hypothesized that younger horses may be less educated or less experienced compared to older horses and may therefore more likely break out from paddocks or buck off their riders and get hit by a motorized vehicle. This however was not the case in this study, where age was homogenously distributed and ranged from $1-21$ years (mean 9.1 years) in the group of horses hit by a motorized vehicle.

Cats commonly present with pelvic trauma following road traffic accidents (Meeson and Corr 2011, Rochlitz 2004). In contrast to the horses reported in this study, where pelvic fractures were not a very common fracture type. Only two horses hit by a motorized vehicle showed fractures in the region of the pelvis and amongst the horses involved in RTAs whilst being transported only one horse had a fracture of the ischial tuberosity. 
The incidence of horses with internal lesions in this study was low $(14.7 \%$ of horses hit by a motorized vehicle and none involved in RTAs whilst being transported). In contrast in dogs and cats internal lesions after being hit by a car are more frequent (Meeson and Corr 2011 1). The horse with the large-scale abdominal wound shown in figure 5 was referred to the Equine Hospital for surgical repair. The 13-year old warmblood gelding was presented after he had escaped from his paddock and collided with a car. Surgical repair of the abdominal wound under general anesthesia was performed. A perforation of the peritonaeum could not be detected at any location. Although the horse recovered well from anaesthesia and the result of the wound closure was satisfying, it had to be euthanized due to severe colic and endotoxemia post-operatively. Necropsy confirmed that the abdominal cavity was not entered. The horse's colon had ruptured due to a blunt trauma. This again highlights the magnitude of force and the transmission of high energy when these accidents happen, even resulting in euthanasia due to the severity of the injury.

\section{Conclusion}

The study showed that wounds were the most common injury type found in horses involved in traffic accidents. Injuries of horses being hit by a motorized vehicle were much more severe than when horses were protected by a trailer and involved in an RTA whilst being transported. The largest part of horses hit by a motorized vehicle was a result of breaking out of the paddock in the winter months highlighting the need to optimize stable and paddock conditions to prevent these potentially life threatening injuries. The study was able to identify the injury pattern of traffic accident-related injuries in horses. Awareness of the nature of these injuries is important to avoid underestimation of their severity. This is especially true in horses, which are hit by motorized vehicles where larger impact forces play a role.

\section{Manufacturer address}

1 Johnson\& Johnson, New Brunswick, New Jersey, USA

\section{Conflict of interest statement}

No competing interests have been declared.

\section{References}

Ball C. G., Ball J. E., Kirkpatrick A. W., Mulloy R. H. (2007) Equestrian injuries: incidence, injury patterns, and risk factors for 10 years of major traumatic injuries. Am. J. Surg. 193, 636-640. DOI: 10.1016/i.amjsurg.2007.01.016

Bundesamt für Strassen ASTRA (2015) Übersicht Standardreports, zuletz† geprüft am 23.11.2015.

Chapman C, Musselwhite C. B. A. (2011) Equine road user safety: public attitudes, understandings and beliefs from a qualitative study in the United Kingdom. Accid. Anal. Prevent. 43, 2173-2181 DOI: 10.1016/i.aap.2011.06.009

Corr S. (2012) Complex and open fractures: a straightforward approach to management in the cat. J. Fel. Med. Surg. 14, 55 64. DOI: $10.1177 / 1098612 \times 11432827$
Eidgenössisches Departement des Innern EDI (2015) Verkehrsunfälle in der Schweiz 2014, zuletz† geprüft am 23.11.2015

Eidgenössisches Departement für Wirtschaft, Bildung und Forschung (2015) Anzahl Pferde in der Schweiz nimmt weiter zu. 3.2_2_FO_1_Vorlage Medienmitteilung ACW-WA_d, zuletz† geprüft am $2 \overline{3} .11 .2015$.

Eidgenössisches Departement für Wirtschaft, Bildung und Forschung (2015)Agroscope: Wirtschafts-, Gesellschafts- und Umweltpolitische Bedeutung des Pferdes in der Schweiz, Stand 2013, zuletz† geprüft am 24.11.2015

Euorpean Commission - Directorate General for Mobility and Transport (2015) EU road fatalities. Online verfügbar unter http://ec.europa.eu/transport/road_safety/pdf/observatory/trends figures.pdf, zuletzt geprüft am 24.1̄1.2015

Ghosh A., Di Scala C., Drew C., Lessin M., Feins N. (2000) Horserelated injuries in pediatric patients. J. Pediatr. Surg. 35, $1766-$ 1770. DOI: 10.1053/ipsu.2000.19247

Hothorn T., Muller J., Held L., Most L., Mysterud A. (2015) Temporal patterns of deer-vehicle collisions consistent with deer activity pattern and density increase but not general accident risk. Accid. Anal. Prevent. 81, 143-152. DOI: 10.1016/i.aap.2015.04.037

Jagodzinski T., DeMuri G. P. (2005) Horse-related injuries in children: a review. WMJ: official publication of the State Medical Society of Wisconsin 104, 50-54

Katic N., Bartolomaeus E., Böhler A., Dupré G. (2007) Traumatic diaphragmatic rupture in a cat with partial kidney displacement into the thorax. J. Small Anim. Pract. 48, 705-708. DOI: 10.1111/i.1748-5827.2007.00336.x

Langbein J., Putman. R. J., Pokorny B. (2011) Road Traffic Collisions involving deer and other ungulates in Europe and available measures for mitigation. Ungulate Management in Europe: Problems and Practices (eds. R. J. Putman, M. Apollonio, R. Andersen), Cambridge University Press, pp. 215-259

Meeson R., Corr S. (2011) Management of pelvic trauma: neurological damage, urinary tract disruption and pelvic fractures. Feline Med. Surg. 13, 347-361. DOI: 10.1016/i.jfms.2011.03.011

Rochlitz I. (2004) Clinical study of cats injured and killed in road traffic accidents in Cambridgeshire. J. Small Anim. Pract. 45, 390-394

Erweiterte Zusammenfassung

\section{Verkehrsunfall-assozierte Verletzungen bei Pferden}

Das Ziel dieser retrospektiven Studie war aufzuzeigen, welche Körperstellen bei Pferden nach Verkehrsunfällen mehrheitlich betroffen waren und um welche Art von Verletzungen es sich handelte (Wunden, muskuloskeletäre Läsionen, innere Verletzungen). Ein weiteres Ziel war es, den Schweregrad der Verletzungen aufzuzeigen. Die Krankengeschichten von Pferden, welche zwischen 1993-2015 in Verkehrsunfälle involviert und an der Pferdeklinik der Vetsuisse Fakultät der Universität Zürich vorgestellt worden sind, wurden retrospektiv untersucht. Sämtliche Pferde wurden in zwei Gruppen unterteilt: I-Pferde welche von einem Fahrzeug angefahren worden sind (Personenwagen, landwirtschaftliche Fahrzeuge, Lastwagen und Motorfahrräder) sowie II-Pferde welche in einem Anhänger stehend verunfallt sind. Folgende Punkte wurden untersucht: Signalement, Hospitalisationsdaver, Monat in welchem der Unfall passiert ist, Grund für den Unfall, Ort wo der Unfall passiert ist und Art des Fahrzeugs, von welchem das Pferd angefahren worden ist. Die verschiedenen Körperstellen (Kopf, Hals, Brust, Vorderextremität, Abdomen, Rücken und Wirbelsäule, Becken und Ileosakralbereich, Hinterextremität, Schweif und Genital) sowie die Art der Verletzung wurden erfasst und weiter unterteilt in Wunden (oberflächlich vs. tief), muskuloskeletale Läsionen (Frakturen, synoviale Strukturen, Sehnenschäden) und innere Verletzungen. Neurologische Ausfälle wurden ebenfalls 
vermerkt. 34 Pferde, welche angefahren worden sind (Gruppe I) und 13 Pferde, welche in einem Anhänger stehend verunfallt sind (Gruppe II), wurden in die Studie miteinbezogen. Pferde der Gruppe I) verzeichneten einen stationären Aufenthalt von durchschnittlich 11,2 Tagen. Die Pferde der Gruppe II) verbrachten durchschnittlich 6,5 Tage stationär an der Klinik. Die meisten Unfälle der Gruppe I) ereigneten sich in den Monaten Oktober (14.7\%) und Dezember (je 14,7\%). Bei der Gruppe II kam es am häufigsten in den Monaten April (30,8\%) und Juni $(23,1 \%)$ zu Unfällen.

29,4\% der Pferde der Gruppe I sind aus ihrem Paddock ausgebrochen und wurden danach angefahren. In 5.9\% der Fälle ist der Reiter vom Pferd gestürzt und in 2,9\% der Fälle wurde das Pferd samt Reiter im Sattel angefahren. In den verbleibenden $61,8 \%$ der Fälle konnte retrospektiv nicht definiert werden, was letzten Endes dazu geführt hat, dass das Pferd angefahren worden ist. In 85,3\% der Fälle wurden die Pferde von Autos angefahren und die meisten Unfälle, sofern ervierbar, ereigneten sich auf Hauptstraßen (26,5\%). Bei Pferden der Gruppe II ereignete sich die Mehrzahl der Unfälle auf Autobahnen (76,9\%). In 15,4\% der Fälle waren Autos und in $30,8 \%$ der Fälle waren Lastwagen an der Kollision beteiligt. In knapp der Hälfte der Fälle ging nicht abschließend aus den Krankengeschichten hervor um welchen Fahrzeugtyp es sich handelte. Von den betroffenen Körperstellen kamen bei Pferden der Gruppe I an erster Stelle die proximale Hinterextremität $(44,1 \%)$, an zweiter Stelle die proximale Vorderextremität $(38,2 \%)$ und an dritter Stelle der Kopf $(32,4 \%)$ vor. Bei den Pferden der Gruppe II waren an erster Stelle die proximalen Vorderextremitäten (61,5\%), an zweiter Stelle die proximale Hinterextremität $(53,8 \%)$ sowie je gleichermaßen an dritter Stelle distale Hinterextremität, Rücken und Kopf betroffen (je $38,5 \%$ ) (Abbildung 3). Wunden waren der häufigste Verletzungstyp bei beiden Gruppen (Gruppe I) 85,3\%, Gruppe II) 76,9\%; Abbildung 4). 35,3\% der Pferde der Gruppe I wiesen Frakturen auf. Bei 20,6\% der Pferde dieser Gruppe war eine synoviale Struktur beteiligt und in 5,9\% der Fälle war eine Sehnenläsion zu verzeichnen. In 14,7\% der Fälle kam es zu inneren Verletzungen. In Gruppe I kam es bei 14,7\% der Fälle zu neurologischen Symptomen, wovon $40 \%$ periphere Nervenschädigungen waren und $60 \%$ zentrale Nervenschädigungen. Bei den Pferden der Gruppe II kam es in 30,8\% der Fälle zu Frakturen. In keinem der Fälle kam es zu Verletzungen synovialer Strukturen oder zu Sehnenschäden. Es wurden auch keine inneren Verletzungen notiert. Lediglich ein Pferd war von zentralen neurologischen Symptomen betroffen.
Diese Studie konnte aufzeigen, dass Pferde, welche in Verkehrsunfälle involviert waren, in erster Linie an Wunden litten, unabhängig davon ob sie während des Transports in einem Anhänger standen, oder angefahren worden sind. Bei den 34 untersuchten Fällen, in welchen Pferde angefahren worden sind (Gruppe I), hatten 85,5\% der Fälle eine oder mehrere Wunden. 65,5\% Prozent dieser Wunden waren oberflächlich, in 34,5\% der Fälle waren es tiefe Wunden, welche mehr als bloss die Haut penetrierten. Bei den 13 untersuchten Pferden, welche in einem Anhänger standen, während sie auf den StraBen verunfallten, litten 76,9\% der Fälle an Wunden. Mit der Ausnahme eines Falles handelte es sich ausschließlich um oberflächliche Wunden. Nur in einem Fall kam es zu oberflächlichen und zusätzlich tiefen Wunden. Hinsichtlich der betroffenen Körperstellen kam es bei Pferden, welche angefahren worden sind, am häufigsten zu Verletzungen im Bereich der proximalen Hinterextremität, gefolgt von Verletzungen der proximalen Vorderextremität und des Kopfes. Bei der Gruppe von Pferden welche in einem Anhänger gestanden haben während des Unfalls, war am häufigsten die proximale Vorderextremität betroffen, gefolgt von Läsionen im Bereich der proximalen Hinterextremität, sowie distale Hintergliedmaße, Rükken und Kopf (Abbildung 3). Die Studie konnte auch aufzeigen, dass sich rund ein Drittel der Unfälle der Gruppe I in den Monaten Oktober und Dezember zugetragen hat (29,4\%). Bei der Gruppe II kam es in gut fünfzig Prozent der Fälle zu Unfällen in den Monaten April und Juni (53,9\%). Die Unfälle führten hauptsächlich zu Wunden Bei Pferden welche angefahren worden sind, war der Hauptgrund für die Kollision das Ausbrechen der Pferde von ihren Unterkünften und Weiden.

Pferde werden in der Schweiz mehrheitlich zu Freizeitzwecken gehalten. Dies in Regionen, die dicht bevölkert und von einem hohen Verkehrsaufkommen betroffen sind. Entsprechend höher ist die Wahrscheinlichkeit, dass Pferde in Verkehrsunfälle involviert werden. Diese Studie konnte die mehrheitlich betroffenen Körperstellen, sowie die Art der Verletzungen nach Verkehrsunfällen ervieren. Die Resultate verdeutlichen, dass der Pferdeanhänger gleichzeitig eine schützende Funktion hat. Pferde der Gruppe I sind insgesamt weniger schwerwiegend verunfallt als Pferde der Gruppe II. Die Kräfte die entstehen wenn ein Pferd in Bewegung mit einem Fahrzeug kollidiert, sind massiv. Der Schweregrad dieser Verletzungen sollte daher nicht unterschätzt werden.

Schlüsselwörter: Verkehr / Pferd / Verletzung / Körperregion / Unfall / Trauma 